\title{
THE MOST IMPORTANT MEDICINAL PLANTS AFFECTING BEE STINGS: A SYSTEMATIC REVIEW STUDY
}

\author{
Arı Sokmalarını Etkileyen Önemli Şifalı Bitkiler: Sistematik Derleme Çalışması
}

\author{
Aliasghar MANOUCHEHRI ${ }^{1}$, Pegah SHAKIB ${ }^{2}$, Fakher BIGLARYAN ${ }^{3}$, Mohammadreza \\ NAZER ${ }^{4}$, Mohammad DARVISHI ${ }^{5,6^{*}}$
}

\begin{abstract}
${ }^{1}$ Department of Internal Medicine, Shahid Beheshti Hospital, Babol University of Medical Sciences, Babol, IRAN, ORCID No: 0000-0003-1741-9791, E-posta: drmanouchehri@yahoo.com

${ }^{2}$ Razi Herbal Medicines Research Center, Lorestan University of Medical Sciences, Khorramabad, IRAN, ORCID No: 00000003-3525-226X, E-posta: shakib.pegah@yahoo.com

${ }^{3}$ Master of Clinical Psychology and Head of the Health Department of Chalous Police, NAJA, Mazandaran, IRAN ORCID No. 0000-0003-3392-1108, E-posta: bigglarian@ymail.com

${ }^{4}$ Department of Infectious Diseases, Lorestan University of Medical Sciences, Khorammabad, IRAN, ORCID No: 00000002-8894-8191, E-posta: dr_nazer@yahoo.com

${ }^{5}$ Infectious Diseases and Tropical Medicinal Research Center (IDTMRC), AJA University of Medical Sciences, Tehran, IRAN ORCID No: 0000-0003-0332-2489

${ }^{6 *}$ Department of Aerospace and Subaquatic Medicine, AJA University of Medical Sciences, Tehran, IRAN, Corresponding Author: E-posta: darvishi1349@gmail.com
\end{abstract}

Geliş Tarihi / Received: 28.02.2021

Kabul Tarihi / Accepted: 17.03.2021

DOI: 10.31467/uluaricilik.887370

\begin{abstract}
Bee stings are one of the most common insect bites. In some insects, including bees, the sting, along with the venom gland, is separates from the bees' body after the bite and remains at the site of the bite. Bee stings are associated with symptoms such as redness of the skin, itching, allergic reactions causing infection, headache, dizziness, nausea, chest pain, suffocation, breathing difficulty, and paralysis of the bite area. This review study was conducted to identify Iranian medicinal plants for the treatment of bee stings. It was used to review articles in Iranian ethnobotanical sources and articles. Keywords such as bee sting, bee sting, medicinal plants, ethnobotany, identification of medicinal plants and Iran were used. Databases such as ISI Web of Science, PubMed, Scopus, ISC, ISID, Magiran and Google Scholar were used to review articles and resources. Medicinal plants such as Aloe vera, Calendula officinalis, Ruta graveolens L., Allium sativum, Heliotropium ramosissimum, Allium cepa L., Taraxacum officinale L., Rosa canina L., Petroselinum crispum, Verbascum songaricum Schrenk., Vitex pseudonegundo, Ment eriophora DC., Peganum harmala L, Citrullus colocynthis, Ocimum basilicum, Curcuma longa were among the most important medicinal plants used in Iranian ethnobotanical sources to treat bee stings. The most common plant families used for bee stings include Asteraceae and Lamiaceae. Also, the most plant organs used in bee stings included leaves $(37 \%)$, shoots $(20 \%)$ and flowers $(14 \%)$. This study lists a number of plants that have been introduced in different parts of Iran as a treatment and antidote against bee stings and bee stings. This study introduces a number of herbs that are used in different parts of Iran as a treatment against bee stings. We believe that the plants can be used as herbal remedies and antidotes against bee stings. Lack of natural, useful and effective drugs for the treatment of bites leads to the expansion of research on effective and natural drugs for patients with bites.
\end{abstract}

Keywords: Bee sting, Medicinal plants, Folk remedy, Traditional medicine, Honey bee 


\section{Öz}

Arı sokmaları en yaygın böcek ısırıklarından biridir. Arılar da dahil olmak üzere bazı böceklerde, zehir beziyle birlikte sokma, Isırmadan sonra arıların vücudundan ayrılır ve ısırık yerinde kalır. Arı sokmaları ciltte kızarıklık, kaşıntı, enfeksiyona neden olan alerjik reaksiyonlar, baş ağıısı, baş dönmesi, mide bulantısı, göğüs ağrısı, boğulma, nefes almada zorluk ve ısırık bölgesinde felç gibi semptomlarla ilişkilidir. Bu inceleme çalışması, arı sokmalarının tedavisi için İran şifalı bitkilerini belirlemek amacıyla yapılmıştır. İran etnobotanik kaynaklarında ve makalelerinde yer alan makaleleri gözden geçirmek için kullanıldı. Arı sokması, arı sokması, şifalı bitkiler, etnobotanik, şifalı bitkilerin tanımlanması ve İran gibi anahtar kelimeler kullanılmıştır. Makaleleri ve kaynakları gözden geçirmek için ISI Web of Science, PubMed, Scopus, ISC, ISID, Magiran ve Google Scholar gibi veritabanları kullanıldı. Aloe vera, Calendula officinalis, Ruta graveolens L., Allium sativum, Heliotropium ramosissimum, Allium cepa L., Taraxacum officinale L., Rosa canina L., Petroselinum crispum, Verbascum songaricum Schrenk., Vitex pseudonegundoora, Ment à., Peganum harmala L, Citrullus colocynthis, Ocimum basilicum, Curcuma longa, İran etnobotanik kaynaklarında arı sokmalarını tedavi etmek için kullanılan en önemli şifalı bitkiler arasındadır. Arı sokmalarında kullanılan en yaygın bitki aileleri arasında Asteraceae ve Lamiaceae bulunur. Ayrıca arı sokmalarında en çok kullanılan bitki organları yapraklar (\%37), sürgünler (\%20) ve çiçeklerdir (\%14). Bu çalışma, İran'ın farklı bölgelerinde arı sokmalarına ve arı sokmalarına karşı bir tedavi ve panzehir olarak tanıtılan bir dizi bitkiyi listeliyor. Bu çalışma, İran'ın farklı bölgelerinde arı sokmalarına karşı bir tedavi olarak kullanılan bir dizi bitkiyi tanıtmaktadır. Bitkilerin bitkisel ilaç ve arı sokmalarına karşı panzehir olarak kullanılabileceğine inanıyoruz. Isırıkların tedavisi için doğal, yararlı ve etkili ilaçların bulunmaması, ısırıkları olan hastalar için etkili ve doğal ilaçlar üzerine araştırmaların genişlemesine yol açmaktadır.

Anahtar Kelimeler: Arı sokmasi, Şifalı bitkiler, Halk ilaçları, Geleneksel tıp, Bal arısı

\section{GENIŞLETILMIŞ TÜRKÇE ÖZET}

Giriş: Arı sokmaları en yaygın böcek ısırıklarından biridir. Arılar da dahil olmak üzere bazı böceklerde, zehir beziyle birlikte sokma, ısırmadan sonra arıların vücudundan ayrılır ve ısırık yerinde kalır. Arı sokmaları ciltte kızarıklık, kaşıntı, enfeksiyona neden olan alerjik reaksiyonlar, baş ağrısı, baş dönmesi, mide bulantısı, göğüs ağrısı, boğulma, nefes almada zorluk ve ısırık bölgesinde felç gibi semptomlarla ilişkilidir. Arı sokmaları çok acı verici ve can sıkıcıdır. Ancak acının yanı sıra kişinin sağığını da tehlikeye atabilir. Sokmanın yeri çok önemlidir. Örneğin arı sokmaları gözlerde çok tehlikelidir. Arı sokmalarına verilen tepkiler ayrıca zehir miktarına ve bağışıklık tepkisine bağlıdır. Giren zehirin miktarı çoklu ısırıklardan kaynaklanıyorsa, vücuda çok fazla zehir girmişse ve arı ısıran kişi, solunum problemleri veya ısırık bölgesinde şiddetli ve hızlı şişlikle karşılaşacak ve bu komplikasyonu tedavi etmek için derhal harekete geçmesi gerekecek ve diğerleri, 1995; King ve diğerleri, 1993). Arı sokmalarının yüksek insidansı nedeniyle ve arı sokmalarını tedavi etmek için özel bir ilaç bulunmadığından veya kullanılan ilaçların birçok yan etkisi olduğundan, arı sokmalarında kullanılabilecek daha az yan etkiye sahip doğal bir ilaç kaynağı kullanmak çok önemli olabilir.

Metodoloji: Bu inceleme, İran'ın kaynaklarında ve makalelerindeki makaleleri gözden geçirmek için yazılmıştır. Bu çalışmada arı sokması, arı sokması, şifalı bitkiler, etno-botanik, şifalı bitkilerin tanımlanması ve İran gibi anahtar kelimeler kullanılmıştır. Makaleleri ve kaynakları gözden geçirmek için ISI Web of Science, PubMed, Scopus, ISC, ISID, Magiran ve Google Scholar gibi veritabanları kullanıldı. Makale girme kriteri, bahsedilen anahtar kelimelerdi ve makaleleri çalışmanın dışında tutma kriteri, her makalenin metninde arı sokmasını önleyici etkiye sahip bitkilerin olmamasıydı.

Bulgular: Buna göre 47 makale arandı ve bulundu ve Üç makalenin tam metin versiyonu bulunamadi. Kaldırılan iki yinelenen makale vardı. Son olarak, 44 makale literatür taraması için gözden geçirildi. 44 makaleden sadece 12'si arı sokmalarının tedavisi için etnobotanik bilgi içeriyordu. Aloe vera, Calendula officinalis, Ruta graveolens L., Allium sativum, Heliotropium ramosissimum, Allium cepa L., Taraxacum officinale L., Rosa canina L., Petroselinum crispum, Verbascum songaricum Schrenk gibi şifalı bitkiler, Vitex pseudonegundoora 
DC, Ment., Peganum harmala L, Citrullus colocynthis, Ocimum basilicum, Curcuma longa, İran etnobotanik kaynaklarında arı sokmalarını tedavi etmek için kullanılan en önemli şifalı bitkiler arasındadır. Arı sokmalarında kullanılan en yaygın bitki aileleri arasında Asteraceae ve Lamiaceae bulunur. Ayrıca arı sokmalarında en çok kullanılan bitki organları yapraklar (\%37), sürgünler (\%20) ve çiçeklerdir (\%14). Arı zehri vücuda zarar verir. Bu yaralanma genellikle ısırığın yakınındaki alanla sınırlıdır ve bazı durumlarda hayatı tehdit edebilecek sistemik ve tehlikeli komplikasyonlara neden olur. Alerjik reaksiyonlar bunları içerir. En tehlikeli ve ölümcül alerjik reaksiyonların yanı sıra ölümlerin çoğu, ısırmadan sonraki ilk saat içinde meydana gelir.Bunu gidermek ve tedavi etmek için önce arı sokması çıkarılmalı ve iltihabı gidermek için bir buz torbası kullanılmalıdır. Ayrıca kaşıntı ve alerjileri önlemek için antihistaminikler alın. Ağrıyı hafifletmek için ağrı kesiciler tavsiye edilir. Bununla birlikte, kimyasal tedavilerin yan etkileri vardır, bu nedenle uygun bir çözüm olarak doğal ilaçlar kullanılabilir.

Sonuç: Bu çalışma, İran'ın farklı bölgelerinde arı sokmalarına ve arı sokmalarına karşı bir tedavi ve panzehir olarak tanıtılan bazı bitkileri listeliyor. Bu çalışma, İran'ın farklı bölgelerinde arı sokmalarına karşı bir tedavi olarak kullanılan bir dizi bitkiyi tanıtmaktadır. Bitkilerin bitkisel ilaç ve arı sokmalarına karşı panzehir olarak kullanılabileceğine inanıyoruz. Isırıkların tedavisi için doğal, yararlı ve etkili ilaçların bulunmaması, ısırıkları olan hastalar için etkili ve doğal ilaçlar üzerine araştırmaların genişlemesine yol açmaktadır.

\section{INTRODUCTION}

Although many insects cause problems with human bites, the insects that are most likely to cause medical problems include bees, common bees, and ants (Oliveira et al., 2007). Among all the insect bites, bee stings should be avoided. Bee stings by themselves may not be a problem, but multiple stings, such as when a beehive falls on a person, can be fatal (Oliveira et al., 2007). Many people are also allergic to bee venom. When bees or wild bees bite, they inject their venom under the surface of the skin. In this case, severe pain, local swelling and redness occur. The pain caused by a bee sting may last for hours or even a day or two (Schumacher et al., 1995; King et al., 1993). Complications of bee stings are red, swollen, itchy, and sometimes painful
(Whitfield et al., 2006; Harpur et al., 2012; Oxley et al., 2020). Bee stings can sometimes cause allergic reactions in some people. Bee stings can also be infected by scratching. Headache, dizziness, nausea, chest pain, suffocation, and difficulty breathing are other symptoms of a bee sting. Also, if the bite is in the ear area, it can cause the toxin to enter the facial nerve, which is located just below the surface of the skin, and cause paralysis of that area of the face (Whitfield et al., 2006; Harpur et al., 2012; Oxley et al., 2020; Bloch et al., 2010). In the treatment of bee stings, it is necessary to pay attention to the fact that there is no specific antidote for bee venom and the treatment depends on the severity of the patient's symptoms. In many cases, they are able to control these allergic reactions (Hoover et al., 2018). Chemical treatments for bee stings include the use of antibiotics, painkillers, and antihistamines, including promethazine, hydroxyzine, loratadine, cetirizine, fexofenadine, or diphenhydramine to prevent allergies and pain (Chen et al., 2016). Among these, one of the treatments used in the treatment of bee stings is the use of complementary medicine (Chen et al., 2016). Indigenous knowledge and traditional medicine can be considered as a part of the unique culture of each land culture (Moayeri et al., 2016; Bahmani et al., 2019; Asfaw and Fentahun, 2020). That knowledge is the findings that have been obtained through experience to adapt to the specific environmental conditions of the ecosystem and have gradually become part of the social and productive systems. Numerous studies have shown that medicinal plants contain antioxidants and effective substances that have many beneficial effects on health and are used for a variety of diseases (Moayeri et al., 2016; Bahmani et al., 2019; Abbasi et al., 2016; Eftekhari, 2020; Zangeneh et al., 2019; Mahdavi et al., 2019; Valadi et al., 2010; Baharvand-Ahmadi et al., 2015).

Bee stings are very painful and annoying. But apart from the pain, it can also endanger a person's health. The location of the sting is very important. For example, bee stings are very dangerous in the eyes. Reactions to bee stings also depend on the amount of venom and the immune response. If the amount of venom entering is due to multiple bites, a lot of venom has entered the body and the bee bite person will face respiratory problems or severe and rapid swelling at the site of the bite and needs immediate action to treat this complication (Schumacher et al., 1995; King et al., 1993). Due to the high incidence of bee stings and since there is no specialized drug to 
treat bee stings or the drugs used have many side effects, so using a natural source of medicine with fewer side effects that can be used in bee stings can be very important.

\section{METHOD FOR REVIEW}

The present review is written to review articles in the sources and articles of the racial people of Iran. In this study, keywords such as bee sting, bee sting, medicinal plants, ethnobotany, identification of medicinal plants and Iran were used. Databases such as ISI Web of Science, PubMed, Scopus, ISC,
ISID, Magiran and Google Scholar were used to review articles and resources. The criterion for entering articles was the mentioned keywords and the criterion for excluding articles from the study was the absence of plants with anti-bee sting effect in the text of each articles. Accordingly, 47 articles were searched and found. Three articles also lacked full text. There were two duplicate articles that were removed. Finally, 44 articles were reviewed for literature review. Out of 44 articles, only 12 articles contained ethnobotanical information for the treatment of bee stings. The flow chart of the search strategy and the inclusion and exit criteria of the articles are specified in Figure. 1.

Figure 1. The criteria and the number of entry and exit articles

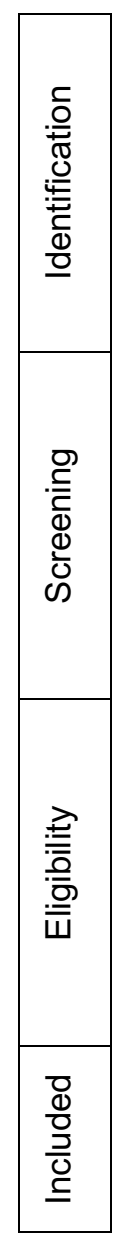

Records identified through database searching by combination of keyword $(n=44)$

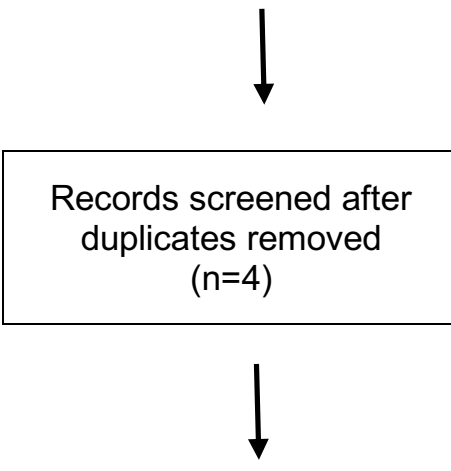

Full-text articles assessed for eligibility $(n=40)$

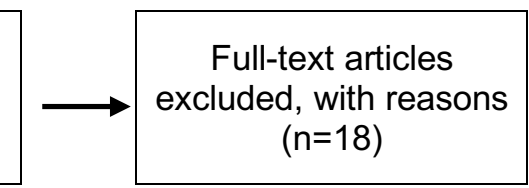

Studies included in systematic review $(n=12)$ 


\section{DERLEME / REVIEW}

\section{RESULTS}

In different regions of Iran, such as northern Iran (northeast Persian Gulf), southern of Iran (Khuzestan, Behbahan, Fasa, Kazerun, Abadeh), eastern Iran (Sistan, Mashhad, Khash), western Iran (Dehloran and Abdanan) and central Iran (regions Central Iran, Jandagh) A group of plants used to treat bee stings. A review of Iranian ethnobotanical sources showed that medicinal plants such as Aloe vera, Calendula officinalis, Ruta graveolens L., Allium sativum, Heliotropium ramosissimum, Allium cepa L., Taraxacum officinale L., Rosa canina L., Petroselinum crispum, Verbascum songaricum Schrenk, Vitex pseudonegundo, Mentha piperit, Achillea eriophora DC., Peganum harmala L, Citrullus colocynthis, Ocimum basilicum, Curcuma longa and also some other plants are among the most important medicinal plants used in Iranian ethnobotanical sources to treat bee stings. The list of plants, families, organs used, and the respective city is given in Table 1 and bioactive compounds, chemical/Molecular formula and figure of medicinal plants affecting bite on Table 2 .

Table 1. Medicinal plants affecting bite and additional information about the organ used, Persian name, region used

\begin{tabular}{|c|c|c|c|c|c|c|}
\hline $\begin{array}{l}\text { Scientific } \\
\text { names }\end{array}$ & Ffamily & Persian name & $\begin{array}{l}\text { Organ } \\
\text { used }\end{array}$ & Region used & $\begin{array}{l}\text { Bioactive } \\
\text { compounds }\end{array}$ & $\begin{array}{l}\text { Chemical } \\
\text { formula }\end{array}$ \\
\hline Aloe vera & Asphodelaceae & Alovera & Leaves & $\begin{array}{l}\text { Behaman (Razmjoue } \\
\text { et al., 2017) }\end{array}$ & Aloesin & $\mathrm{C}_{19} \mathrm{H}_{22} \mathrm{O}_{9}$ \\
\hline $\begin{array}{l}\text { Calendula } \\
\text { officinalis }\end{array}$ & $\begin{array}{l}\text { Asteraceae Pot } \\
\text { marigold }\end{array}$ & Pot marigold & flowers & $\begin{array}{l}\text { Behaman (Razmjoue } \\
\text { et al., 2017) }\end{array}$ & $\alpha$-cadinol & $\mathrm{C}_{15} \mathrm{H}_{26} \mathrm{O}$ \\
\hline $\begin{array}{l}\text { Ruta graveolens } \\
\mathrm{L} \text {. }\end{array}$ & Rutaceae & Common rue & $\begin{array}{l}\text { Aerial } \\
\text { organs }\end{array}$ & $\begin{array}{l}\text { Behaman (Razmjoue } \\
\text { et al., } 2017\end{array}$ & Rutin & $\mathrm{C}_{27} \mathrm{H}_{30} \mathrm{O}_{16}$ \\
\hline Allium sativum & Amaryllidaceae & Garlic & Onion & $\begin{array}{l}\text { Jandagh (Ghasemi } \\
\text { Dehkordi et al., 2012) }\end{array}$ & Alliin & $\mathrm{C}_{6} \mathrm{H}_{11} \mathrm{NO}_{3} \mathrm{~S}$ \\
\hline $\begin{array}{l}\text { Heliotropium } \\
\text { ramosissimum }\end{array}$ & Boraginaceae & $\begin{array}{l}\text { Aftabparaste } \\
\text { porshkhe }\end{array}$ & Leaves & $\begin{array}{l}\text { Jandagh (Ghasemi } \\
\text { Dehkordi et al., 2012) }\end{array}$ & $\beta$-amyrin & $\mathrm{C}_{30} \mathrm{H}_{50} \mathrm{O}$ \\
\hline Allium cepa L. & Amaryllidaceae & Piaz & Onion & $\begin{array}{l}\text { Khuzestan } \\
\text { (Khodayari et al., } \\
\text { 2012) }\end{array}$ & Phenol & $\mathrm{C}_{6} \mathrm{H}_{5} \mathrm{OH}$ \\
\hline $\begin{array}{l}\text { Taraxacum } \\
\text { officinale } \mathrm{L} .\end{array}$ & Asteraceae & Dandelion & flowers & $\begin{array}{l}\text { Khuzestan } \\
\text { (Khodayari et al., } \\
\text { 2012) }\end{array}$ & Phenol & $\mathrm{C}_{6} \mathrm{H}_{5} \mathrm{OH}$ \\
\hline Rosa canina L. & Rosaceae & Dog rose & Fruits & $\begin{array}{l}\text { Khuzestan } \\
\text { (Khodayari et al., } \\
\text { 2012) }\end{array}$ & Oleanolic acid & $\mathrm{C}_{30} \mathrm{H}_{48} \mathrm{O}_{3}$ \\
\hline $\begin{array}{l}\text { Petroselinum } \\
\text { crispum }\end{array}$ & Apiaceae & Parsley & Leaves & $\begin{array}{l}\text { Khuzestan } \\
\text { (Khodayari et al., } \\
\text { 2012) }\end{array}$ & Coumarin & $\mathrm{C}_{9} \mathrm{H}_{6} \mathrm{O}_{2}$ \\
\hline $\begin{array}{l}\text { Verbascum } \\
\text { songaricum } \\
\text { Schrenk. }\end{array}$ & Scrophulariaceae & Benje mari & $\begin{array}{l}\text { Aerial } \\
\text { organs }\end{array}$ & $\begin{array}{l}\text { Khuzestan } \\
\text { (Khodayari et al., } \\
\text { 2012) }\end{array}$ & Butanoic acid & $\mathrm{CH}_{3} \mathrm{CH}_{2} \mathrm{CH}_{2} \mathrm{CO}_{2} \mathrm{H}$ \\
\hline $\begin{array}{l}\text { Vitex } \\
\text { pseudonegundo }\end{array}$ & Verbenaceae & Bangrou & $\begin{array}{l}\text { Leaves } \\
\text { and } \\
\text { flowers }\end{array}$ & $\begin{array}{l}\text { Khuzestan } \\
\text { (Khodayari et al., } \\
\text { 2012) }\end{array}$ & 1,8-Cineole & $\mathrm{C}_{10} \mathrm{H}_{18} \mathrm{O}$ \\
\hline Mentha piperita & Lamiaceae & $\begin{array}{l}\text { Mentha } \\
\text { longifolia var. } \\
\text { asiatica }\end{array}$ & Leaves & $\begin{array}{l}\text { Northeast Persian } \\
\text { Gulf (Rajaei et al., } \\
\text { 2012) }\end{array}$ & Menthol & $\mathrm{C}_{10} \mathrm{H}_{20} \mathrm{O}$ \\
\hline $\begin{array}{l}\text { Achillea } \\
\text { eriophora DC. }\end{array}$ & Asteraceae & Yarrow & $\begin{array}{l}\text { Leaves } \\
\text { and } \\
\text { flowers }\end{array}$ & $\begin{array}{l}\text { Northeast Persian } \\
\text { Gulf (Rajaei et al., } \\
\text { 2012) }\end{array}$ & Camphor & $\mathrm{C}_{10} \mathrm{H}_{16} \mathrm{O}$ \\
\hline $\begin{array}{l}\text { Heliotropium } \\
\text { europaeu }\end{array}$ & Boraginaceae & Aftabparast & Leaves & $\begin{array}{l}\text { Fasa (Ramezanian et } \\
\text { al., 2016) }\end{array}$ & Phytol & $\mathrm{C}_{20} \mathrm{H}_{40} \mathrm{O}$ \\
\hline $\begin{array}{l}\text { Peganum } \\
\text { harmala L. }\end{array}$ & Zygophyllaceae & $\begin{array}{l}\text { Peganum } \\
\text { harmala }\end{array}$ & $\begin{array}{l}\text { Fruits and } \\
\text { Leaves }\end{array}$ & $\begin{array}{lr}\text { Dehloran } & \text { and } \\
\text { Abdanan } & \text { (Ghasemi } \\
\text { Pirbalouti et al., 2013) }\end{array}$ & Harmaline & $\mathrm{C}_{13} \mathrm{H}_{14} \mathrm{~N}_{2} \mathrm{O}$ \\
\hline $\begin{array}{l}\text { Citrullus } \\
\text { colocynthis }\end{array}$ & Curcubitaceae & Squash & Fruits & $\begin{array}{l}\text { Sistan and } \\
\text { Baluchestan } \\
\text { (Dolatkhahi et al., } \\
\text { 2012) }\end{array}$ & Anthrano & $\mathrm{C}_{14} \mathrm{H}_{10} \mathrm{O}$ \\
\hline $\begin{array}{l}\text { Heliotropium } \\
\text { europaeum L. }\end{array}$ & Boraginaceae & Aftabparast & $\begin{array}{l}\text { Aerial } \\
\text { organs }\end{array}$ & $\begin{array}{l}\text { Kazeroun } \\
\text { (Iranmanesh et al., } \\
\text { 2010) }\end{array}$ & Kaempferol & $\mathrm{C}_{15} \mathrm{H}_{10} \mathrm{O}_{6}$ \\
\hline
\end{tabular}


DERLEME / REVIEW

\begin{tabular}{|c|c|c|c|c|c|c|}
\hline $\begin{array}{l}\text { Calotropis } \\
\text { procera }\end{array}$ & Apocynaceae & $\begin{array}{l}\text { Calotropis } \\
\text { procera }\end{array}$ & $\begin{array}{l}\text { Leaves } \\
\text { and } \\
\text { branches }\end{array}$ & $\begin{array}{l}\text { Khash (Mirshekar et } \\
\text { al., 2019) }\end{array}$ & Quercetin & $\mathrm{C}_{15} \mathrm{H}_{10} \mathrm{O}_{6}$ \\
\hline $\begin{array}{l}\text { Hyssopus } \\
\text { officinalis }\end{array}$ & Lamiaceae & Hyssop & Leaves & $\begin{array}{l}\text { Central Regions of } \\
\text { Iran (Mirshekar et al., } \\
\text { 2019) }\end{array}$ & Isopinocamphone & $\mathrm{C}_{10} \mathrm{H}_{16} \mathrm{O}$ \\
\hline $\begin{array}{l}\text { Ocimum } \\
\text { basilicum }\end{array}$ & Lamiaceae & Basil & Leaves & $\begin{array}{l}\text { Khuzestan } \\
\text { (Khodayari et al., } \\
\text { 2015) }\end{array}$ & Methyl eugenol & $\mathrm{C}_{11} \mathrm{H}_{14} \mathrm{O}_{2}$ \\
\hline $\begin{array}{l}\text { Dracocephalum } \\
\text { spp. }\end{array}$ & Lamiaceae & Dracocephalum & $\begin{array}{l}\text { Aerial } \\
\text { organs }\end{array}$ & $\begin{array}{l}\text { Khuzestan } \\
\text { (Khodayari et al., } \\
\text { 2015) }\end{array}$ & Eucalyptol & $\underline{\mathrm{C}_{10} \mathrm{H}_{18} \mathrm{O}}$ \\
\hline Curcuma longa & Zingiberaceae & Turmeric & $\begin{array}{l}\text { Aerial } \\
\text { organs }\end{array}$ & $\begin{array}{l}\text { Northeast Persian } \\
\text { Gulf (Rajaei et al., } \\
\text { 2012) }\end{array}$ & Curcumin & $\mathrm{C}_{21} \mathrm{H}_{20} \mathrm{O}_{6}$ \\
\hline Artemisia aucheri & Asteraceae & Mugworts & $\begin{array}{l}\text { Seeds and } \\
\text { flowering } \\
\text { branches }\end{array}$ & $\begin{array}{l}\text { Fasa (Ramezanian et } \\
\text { al., 2016) }\end{array}$ & Camphene & $\mathrm{C}_{10} \mathrm{H}_{16}$ \\
\hline Thymus vulgaris & Lamiaceae & Thymes & $\begin{array}{l}\text { Aerial } \\
\text { organs }\end{array}$ & $\begin{array}{lr}\text { Dehloran } & \text { and } \\
\text { Abdanan (Ghasemi } \\
\text { Pirbalouti et al., 2013) }\end{array}$ & Thymol & $\mathrm{C}_{10} \mathrm{H}_{14} \mathrm{O}$ \\
\hline $\begin{array}{l}\text { Doronicum } \\
\text { pardalianches L. }\end{array}$ & Asteraceae & Darvaj & Root & $\begin{array}{l}\text { Sistan and } \\
\text { Baluchestan } \\
\text { (Dolatkhahi et al., } \\
\text { 2012) }\end{array}$ & Germacrene D & $\mathrm{C}_{15} \mathrm{H}_{24}$ \\
\hline
\end{tabular}

Table 2. Bioactive compounds, chemical/Molecular formula and figure of medicinal plants affecting bite

\begin{tabular}{|c|c|c|}
\hline Bioactive compounds & Chemical formula & $\mathrm{C} 19 \mathrm{H} 22 \mathrm{O} 9$ \\
\hline Aloesin & Figure of molecular formula \\
\hline$\alpha-c a d i n o l$ & $\mathrm{C}_{15} \mathrm{H}_{26} \mathrm{O}$ & \\
\hline
\end{tabular}




\section{DERLEME / REVIEW}

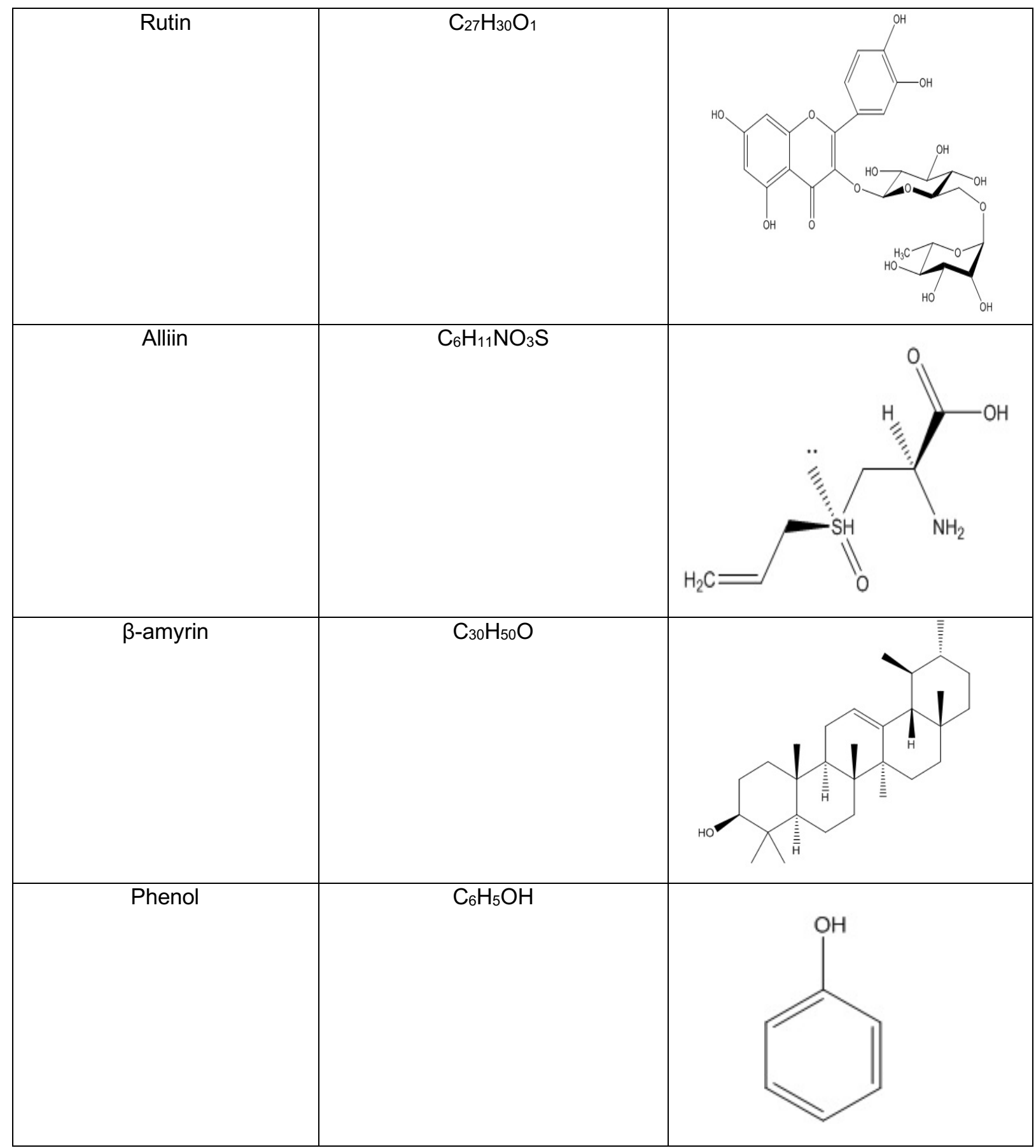

Uludağ Arıcılık Dergisi - Uludag Bee Journal 2021, 21 (1): 91-103 
DERLEME / REVIEW

\begin{tabular}{|l|c|}
\hline Oleanolic acid & $\mathrm{C}_{30} \mathrm{H}_{48} \mathrm{O}_{3}$ \\
\hline Coumarin & $\mathrm{C}_{9} \mathrm{H}_{6} \mathrm{O}_{2}$ \\
\hline Butanoic acid & $\mathrm{CH}_{3} \mathrm{CH}_{2} \mathrm{CH}_{2} \mathrm{CO}_{2} \mathrm{H}$ \\
\hline 1,8-Cineole & $\underline{\mathrm{C}_{10} \mathrm{H}_{18} \mathrm{O}}$ \\
\hline & \\
\hline Menthol & \\
\hline
\end{tabular}




\begin{tabular}{|c|c|c|}
\hline Camphor & \\
\hline Phytol & & \\
\hline Harmaline & & \\
\hline Anthranol & $\mathrm{C}_{13} \mathrm{H}_{14} \mathrm{~N}_{2} \mathrm{O}$ \\
\hline & $\mathrm{C}_{20} \mathrm{H}_{40} \mathrm{O}$ & \\
\hline
\end{tabular}

As shown in figure 1, the most common plant families used for bee stings are Asteraceae and Lamiaceae. Also, most of the plant organs used in bee stings included leaves (37\%), shoots (20\%) and flowers with $14 \%$. Other additional information in this regard is shown in figure 1. 


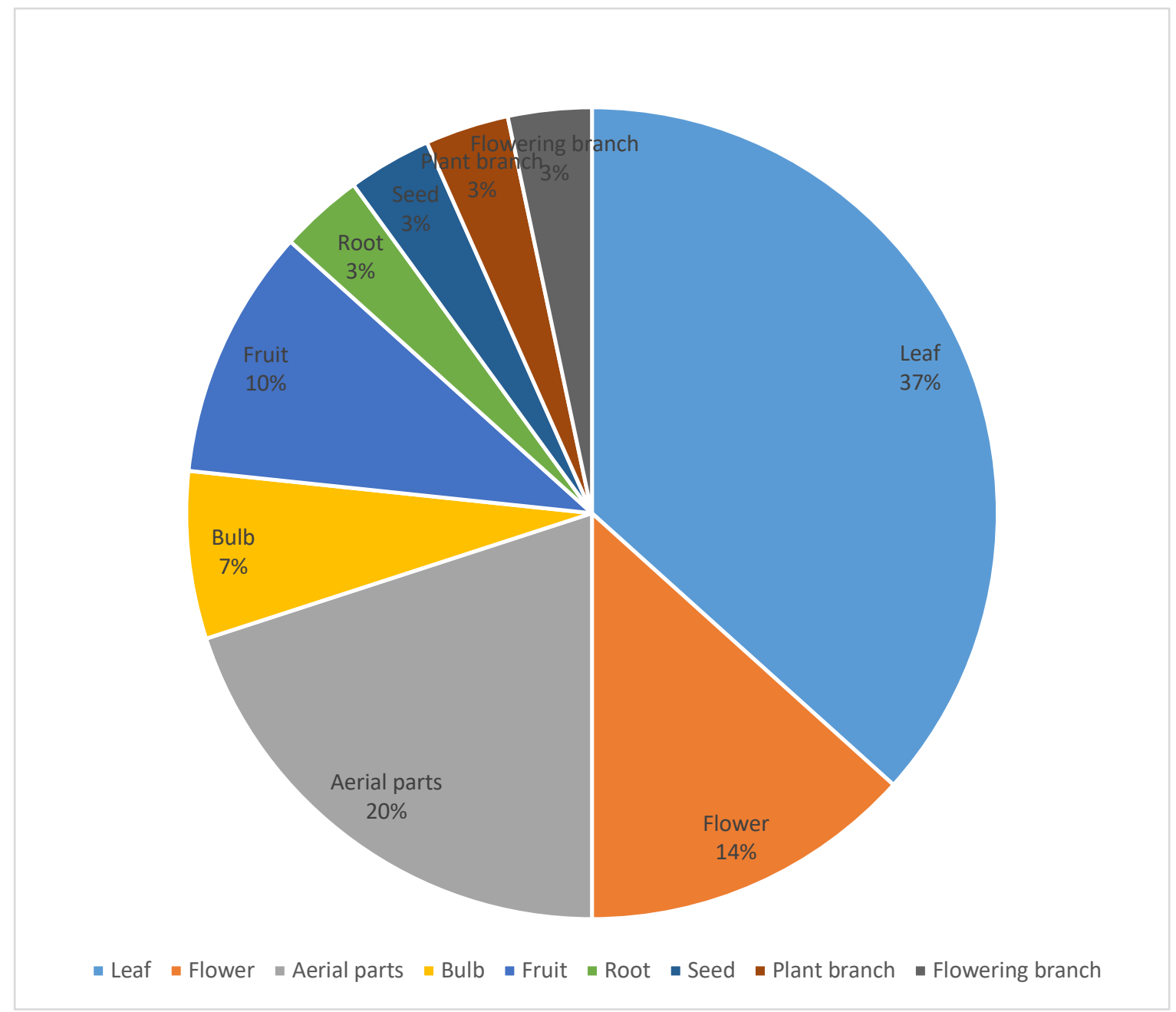

Figure 1. Percentage of use of plant organs for bee stings in this study

\section{DISCUSSION}

Bee venom causes damage to the body. This injury is usually limited to the area near the bite and in some cases causes systemic and dangerous complications that can even be life threatening. Allergic reactions include these. Most dangerous and deadly allergic reactions, as well as most deaths, occur within the first hour after the bite (Hoover and Ovinge, 2018; Chen et al., 2016). In cases of bee stings, symptoms such as swelling of the lips, tingling in the hands, hypotension and dizziness, severe shortness of breath and anesthesia should occur, the person should go to the emergency room and be treated. In this case, the socalled medical person suffers from anaphylactic shock. If a person suffers from this shock, the next time the bee stings, they should inject $0.1 \mathrm{cc}$ ampoule of epinephrine, which is a subcutaneous ampule, before going to the emergency room. In the absence of the above symptoms, the sting is accompanied by severe swelling and pain. To relieve and treat it, the bee sting must first be removed and an ice pack must be used to relieve the inflammation. Also take antihistamines to prevent itching and allergies. Painkillers are recommended to relieve pain. However, chemical treatments have side effects, so natural remedies can be used as a suitable solution (Shakib et al., 2020; Karimian, 2019). 
Traditional medicine and ethnobotanical knowledge for most diseases have herbal prescriptions. In this study, it was found that in Iran, medicinal plants such as Aloe vera, Calendula officinalis, Ruta graveolens L., Allium sativum, Heliotropium ramosissimum, Allium cepa L., Taraxacum officinale L., Rosa canina L., Petroselinum crispum, Verbascum songaricum Schrenk, Vitex pseudonegundo, Mentha piperita, Achillea eriophora DC., Peganum harmala L, Citrullus colocynthis, Ocimum basilicum, Curcuma longa and also some other plants are among the most important medicinal plants used in Iranian ethnobotanical sources to treat bee stings. In the knowledge of traditional Indian medicine Medicinal plants such as Acanthus ilicifolius Linn., Achyranthes aspera Linn., Aconitum balfourii (Bruhl) Muk. Adiantum lunulatum Linn., Aegle marmelos (Linn.) Correa, Aerva lanata (L.) Juss. Ex Schult, Allium cepa Linn., Citrullus colocynthis (Linn) Schrad., Allium sativum Linn, Butea monosperma (Lamk.) Taub are used in cases of venomous bites (snakes) (Khan er al., 2014; Singh et al., 2012; Ayyanar et al., 2011; Alagesaboopathi et al., 2013).

Another study found that Mimosa pudica, Soymida febrifuga, and Tephrosia purpurea were used in cases of bites (Kunjam et al., 2013). In Iranian medicine, medicinal plants such as Ruta graveolens L., Allium cepa L., Vitex pseudonegundo, Artemisia aucheri and Doronicum pardalianches $\mathrm{L}$. are used to treat scorpion bites and snake bites (Astaraki et al., 2019). The results of studies showed that the native medicinal plants of each region are diverse and different in the discussion of bites, and the reason is the medicinal cultures and experimental knowledge of different regions, which are different. It can be said that medicinal plants are used not in raw form in the form of plants but as effective herbal medicines in the treatment of diseases (Alizadeh et al., 2018; Abbaszadeh et al., 2018; Sedighi et al., 2019; Nouri et al., 2019; Gholami-Ahangaran et al., 2020; Salahvarzi et al., 2020; Baharvand-Ahmadi et al., 2015).

This article lists a number of plants that have been introduced in different parts of Iran as a treatment and antidote against bee stings and bee stings . Based on the knowledge of traditional and ethnoherbal medicine of Iran, we believe that they can be used as medicine and herbal antidotes against bites, especially bee stings .Existence of interest and knowledge in this science in different Iranian ethnic groups has led to the use of valuable methods for finding new medicinal plants and herbal remedies against bee stings. Lack of natural, useful and effective drugs for the treatment of bites leads to the expansion of research on effective and natural drugs for patients with bites.

\section{Conflicts of interest}

The authors declared no competing interests.

\section{Ethical considerations}

Ethical issues (including plagiarism, data fabrication, double publication and etc.) have been completely observed by author.

\section{Funding/Support}

None.

\section{REFERENCES}

Abbasi, N, Khosravi, A, Aidy, A, Shafiei, M. 2016. Biphasic response to luteolin in MG-63 osteoblast-like cells under high glucoseinduced oxidative stress. Iran J Med Sci. 41(2): 118-125.

Abbaszadeh, S, Andevari, AN, Koohpayeh, A, Naghdi, N, Alizadeh, M, Beyranvand, F, Harsej, Z. 2018. Folklore medicinal plants used in liver disease: A review. Int $\mathrm{J}$ Green Pharma. 12(3): 463-472.

Alagesaboopathi, C. 2013. Ethnomedicinal plants used for thetreatment of snake bites by Malayali tribals and rural peoplein Salem district, Tamilnadu, India. Int J Biosci. 3: 4253.

Alizadeh, M, Safarzadeh, A, Bahmani, M, Beyranvand, F, Rafieian-Kopaei, M, Abbaszadeh, S. 2018. Brucellosis: Pathophysiology and new promising treatments with medicinal plants and natural antioxidants. Asian Pacific J Trop Med. 11(11): 597-608.

Asfaw M and Fentahun T (2020). Treatment trials of epizootic lymphangitis with local medicinal plants: a review. Online Journal of Animal and Feed Research, 10(4): 158-161.

Astaraki, P, Basati, G, Abbaszadeh, S, Mahmoudi, GA. 2019. A review of medicinal plants used for snakebites and scorpion stings in Iran: A systematic review. Res J Pharmacy Technol. 13(3): 1565-1569.

Ayyanar, M, Ignacimuthu, S. 2011. Ethnobotanical survey ofmedicinal plants commonly used by 
Kani tribals inTirunelveli hills of Western Ghats, India. J Ethnopharmacol. 134: 851-64.

Baharvand-Ahmadi, B., Bahmani, M., Naghdi, N., Saki, K., Sara, Baharvand-Ahmadi, RafieianKopaei, M. 2015. Medicinal plants used to treat infectious and non-infectious diseases of skin and skin appendages in city of Urmia, northwest Iran. Der Pharmacia Lettre. 7 (11): 189-196.

Baharvand-Ahmadi, B., Bahmani, M., Zargaran, A., Eftekhari, Z., Saki, K., Baharvand-Ahmadi, S., Rafieian-Kopaei, M. 2015. Ruta graveolens plant: A plant with a range of high therapeutic effect called cardiac plant. Der Pharmacia Lettre. 7 (11): 172-173.

Bahmani, M, Taherikalani, M, Khaksarian, M, Rafieian-Kopaei, M, Ashrafi, B, Nazer, M, Soroush S. Abbasi N, Rashidipour M. 2019. The synergistic effect of hydroalcoholic extracts of Origanum vulgare, Hypericum perforatum and their active components carvacrol and hypericin against Staphylococcus aureus. Future Sci OA. 5(3): Article number FSO371.

Bahmani, M., Mozaffari Nejad, A.S., Shah, N.A., Shah, S.A., Rafieian-Kopaei, M., Mahmoodnia, L. 2017. Survey on ethnobotanical uses of anti-cancer herbs in southern region of Ilam, west Iran. J Biolog Res. 90 (1): 5939.

Bloch, G, Francoy, TM, Wachtel, I, Panitz-Cohen, N, Fuchs, S, Mazar, A. 2010. Industrial apiculture in the Jordan valley during Biblical times with Anatolian honeybees. Proc Natl Acad Sci. 107:11240-4.

Chen, J, Guan, S-M, Sun, W, Fu H. 2016. Melittin, the major pain-producing substance of bee venom. Neurosci Bull. 32:265-72.

Dolatkhahi, M, Ghorbani-Nahouji, M, Mehrafarin, A, AminiNezjad, GHR, Dolatkhahi, A. 2012. Ethnobotanical study of medicinal plants in Kazerun city: Identification, distribution and traditional uses. J Med Plants. 11(2): 163-178.

Eftekhari, Z. 2020. Garlic: A brief overview of its interaction with chemical drugs. Plant Biotechnol Persa. 2 (2): 31-32.

Ghasemi Dehkordi, N, Nourouzi, M, SafaeiAziz, A. 2012. Collecting and reviewing selected

\section{DERLEME / REVIEW}

traditional uses of plants in Jandagh. J Islamic Iranian Tradition Med. 3(1): 105-112.

Ghasemi Pirbalouti, A, Momeni, M, Bahmani, M. 2013. Ethnobotanical Study of Medicinal Plants Used by Kurd Tribe in Dehloran and Abdanan Districts, Ilam Province, Iran. Afr J Tradit Complement Altern Med. 10(2):368000.

Gholami-Ahangaran, M, Ostadpoor, M, Heidari, S H. 2020. An Overview of Cinnamon Properties Effects on Blood Glucose and Hemoglobin A1C in Diabetic People. Plant Biotechnol Persa. 2 (2): 33-37.

Harpur, BA, Minaei, S, Kent, CF, Zayed, A. 2012. Management increases genetic diversity of honey bees via admixture. Mol Ecol. 21:441421.

Hoover, SE, Ovinge, LP. 2018. Pollen collection, honey production, and pollination services: managing honey bees in an agricultural setting. J Econ Entomol. 111:1509-16.

Iranmanesh, M, Najafi, SH, Yousefi, M. 2010. Ethnobotany study of medicinal plants in Sistan region. J Herb drugs. 2: 61-.68.

Karimian, M. 2019. Natural remedies for vascular diseases. Plant Biotechnol Persa. 1 (1):1-3.

Khan, AV, Ahmed, QU, Khan, MW, Khan, AA. 2014. Herbal cure forpoisons and poisonous bites from Western Uttar Pradesh, India. Asian Pacific J Trop Dis. 4: 116-20.

Khodayari, H, Amani, SH, Amiri, H. 2015. Ethnobotanical study of medicinal plants in different regions of Khuzestan province. Ecophytochemical J Med Plants. 8(2):12-6.

King, TP, Coscia, MR, Kochoumian, L. 1993. Structure-immunogenicity relationship of melittin and its $\mathrm{N}$-terminal truncated analogs. Biochem. 32:3506-10.

Kunjam, SR, Jadhav, SK, and Tiwari, KL. 2013. Traditional Herbal Medicines for the Treatment of Snake Bite and Scorpion Sting by the Tribes of South Surguja, Chhattisgarh, India. Med Aromat Plants. 2:1; doi.org/10.4172/2167-0412.1000120.

Mahdavi, B, Saneei, S, Qorbani, M, Zhaleh, M, Zangeneh, A, Zangeneh, MM, Pirabbasi, E, Abbasi, N, Ghaneialvar, H. 2019. Ziziphora clinopodioides Lam leaves aqueous extract mediated synthesis of zinc nanoparticles and 


\section{DERLEME / REVIEW}

their antibacterial, antifungal, cytotoxicity, antioxidant, and cutaneous wound healing properties under in vitro and in vivo conditions. ApplOrganometallic Chem. 33 (11): no. 5164.

Mirshekar, M, Ebrahimi, M, Ajorlo, M. 2019. Ethnobotanical study and traditional uses of some medicinal plants in Khash city. J Islamic Iranian Tradition Med. 9 (4): 361-371.

Moayeri, A, Azimi, M, Karimi, E, Aidy, A, Abbasi, N. 2018. Attenuation of Morphine Withdrawal Syndrome by Prosopis Farcta Extract and Its Bioactive Component Luteolin in Comparison with Clonidine in Rats. Med Sci Monitor Basic Res. 24(9): 151-158.

Nouri, A, Heidarian, E, Amini-Khoei, H, Abbaszadeh, S, Basati, G. 2019. Quercetin through mitigation of inflammatory response and oxidative stress exerts protective effects in rat model of diclofenac-induced liver toxicity. J Pharma Pharmacog Res. 7(3): 200-212.

Oliveira, EC, Pedroso, PM, Meirelles, AE, Pescador, CA, Gouvêa, AS, Driemeier, D. 2007. Pathological findings in dogs after multiple Africanized bee stings. Toxicon. 49:1214-8.

Oxley, PR, Oldroyd, BP. 2020. Chapter 3-the genetic architecture of honeybee breeding. Adv Insect Physiol. 39:83-118.

Rajaei, P, Mohamadi, N. 2012. Ethnobotanical study of medicinal plants of Hezar mountain allocated in South East of iran. Iran J Pharm Res. 11(4):1153-67.

Ramezanian, M, MinaeiFar, AA. 2016. Ethnobotanical study of medicinal plants in Fasa county. J Islamic Iranian Tradition Med. $7(2): 221-31$.

Razmjoue D, Zarei Z, Armand R. 2017. Ethnobotanical study (identification, medical properties and how to use) of some medicinal plants of Behbahan city of Khuzestan province, Iran. Journal of Medicinal Plants. 16(64):33-50.
Salahvarzi, S, Shakib, P, Pirhadi, M, Alikord, M, Jahed Khaniki, G. 2020. Helicobacter Phytotherapy: Medicinal Plants Affecting Helicobacter Pylori Infection in Iran. Plant Biotechnol Persa. 2 (2): 38-42.

Schumacher, MJ, Egen, NB. 1995. Significance of Africanized bees for public health: a review. Arch Intern Med. 155: 2038-43.

Sedighi, M, Sewell, R.D.E, Nazari, A, Abbaszadeh, S, Cheraghi, M, Amini, A, Heydari, Z, Rafieian-Kopaei, M. 2019. A review on the most important medicinal plants effective in cardiac ischemia-reperfusion injury. Curr Pharmac Design. 25(3): 352-358.

Shakib, P, Bahmani, M, Parsaee, P. 2020. Drug Interaction of Glycyrrhiza glabra L. with Chemical Drugs: A mini Review Article. Plant Biotechnol Persa. 2 (2): 28-30.

Singh, EA, Kamble, SY, Bipinraj, NK, Jagtap, SD. 2012. Medicinalplants used by the Thakar tribes of Raigad district, Maharashtra for the treatment of snake-bite andscorpion-bite. Int J Phytother Res. 2: 26-35.93.

Valadi, A, Nasri, S, Abbasi, N, Amin, GR. 2010. Antinociceptive and anti-inflammatory effects of hydroalchoholic extract of Anethum graveolens L. seed. J Med Plants. 9(34):124130.

Whitfield, CW, Behura, SK, Berlocher, SH, Clark, AG, Johnston, JS, Sheppard, WS, et al. 2006. Thrice out of Africa: ancient and recent expansions of the honey bee, Apis mellifera. Science, 314: 642-5.

Zangeneh, MM, Ghaneialvar, H, Akbaribazm, M, Ghanimatdan, M, Abbasi, N, Goorani, S, Pirabbasi, E, Zangeneh, A. 2019. Novel synthesis of Falcaria vulgaris leaf extract conjugated copper nanoparticles with potent cytotoxicity, antioxidant, antifungal, antibacterial, and cutaneous wound healing activities under in vitro and in vivo condition. $J$ Photochem Photobiol B: Biol. 197: no. 111556. 